\title{
Regionalized cell proliferation in the symbiont-bearing gill of the hydrothermal vent mussel Bathymodiolus azoricus
}

\author{
Piquet Bérénice 1, 2, 3, Lallier François H. ${ }^{1}$, André Coralie ${ }^{1}$, Shillito Bruce ${ }^{2}$, Andersen Ann C. 1, ${ }^{*}$,
} Duperron Sébastien ${ }^{3,4},{ }^{*}$

\begin{abstract}
${ }^{1}$ Lab. Adaptation et Diversité en Milieu Marin, AD2M, Adaptation et Biologie des Invertébrés marins en Conditions Extrêmes (UMR 7144), ABICE, DYDIV, Station Biologique de Roscoff, Sorbonne Université CNRS, place Georges Teissier, Roscoff, France

${ }^{2}$ Laboratoire de Biologie des Organismes et Ecosystèmes Aquatiques (BOREA), MNHN, CNRS-2030, IRD-207, Sorbonne Université, UCN, UA, Team: Adaptation aux Milieux Extrêmes (AMEX), 7 Quai Saint-Bernard, Paris, France

${ }^{3}$ Muséum National d'Histoire Naturelle, CNRS, Lab. Mécanismes de Communication et Adaptation des Micro-organismes (UMR 7245), Team: Cyanobactéries, Cyanotoxines et Environnement, CCE, PTME 12 rue Buffon, Paris, France

${ }^{4}$ Institut Universitaire de France, Paris, France

* Corresponding authors : Ann C. Andersen, email address : andersen@sb-roscoff.fr ; Sébastien

Duperron, email address : sebastien.duperron@mnhn.fr
\end{abstract}

\begin{abstract}
:
Deep-sea mussels Bathymodiolus spp. harbor high densities of chemosynthetic bacterial symbionts located within their gill epithelial cells. Compared to non-symbiotic coastal mussel relatives of similar size, Bathymodiolus gills are considerably larger, a feature often considered an adaptation to symbiosis because it is related to the presence of intracellular bacteria in epithelial cells located in the lateral zone. In order to document the mechanisms underlying these sizes differences, this study compares gill cell proliferation patterns in Bathymodiolus azoricus and Mytilus edulis using microscopy-based approaches. We used incubation experiments with a synthetic nucleotide (5-ethynyl 2'-deoxyuridine, EdU), detectable throughout novel cell divisions, and phosphohistone $\mathrm{H} 3$ immunolabeling, a marker of mitosis. The results revealed proliferation areas in the ciliated zone and in the bacteria-loaded bacteriocytes located close to the frontal zone of gill filaments, swept by the incurrent sea-waterflow, and also in the dorsal region of gills in B. azoricus. Cell proliferation seems far less intensive in M. edulis. This study overall suggests high cell turnover and fast tissue dynamics in symbiont-bearing mussels.
\end{abstract}

Keywords : Bathymodiolus, EdU, Phosphohistone H3, Hydrothermal vents, Cell division, Chemotrophic symbiosis 
Tissues and organs that have evolved to host intracellular microorganisms are common in various animal taxa, including the endoderm of cnidarians, insect bacteriomes, and the trophosome of deep-sea tubeworms (Russel and Ruelas Castillo, 2020). In a multicellular organism, the number of microbes within each host cell, as well as the size of symbiont-hosting tissues must be regulated in a way that does not compromise proper host development and maintenance. However, to understand the adaptations that underpin an organ's ability to host symbionts, a comparative approach is mandatory, in which patterns can be compared in the same organ between symbiont-containing and non-symbiotic related species.

Large Bathymodiolinae mussels from deep-sea hydrothermal vents and cold seeps offer an interesting opportunity to study how an organ may evolve to become symbiotic. As members of the family Mytilidae, symbiotic Bathymodiolinae can be compared with coastal Mytilidae that have no symbionts. The gills of adult Bathymodiolinae indeed harbor bacterial symbionts in high densities, in the range of $10^{12}$ per individual, within specialized gill epithelial cells named bacteriocytes. Their gills are enlarged, representing an exchange surface about 20-fold larger than that of a similar-sized Mytilus edulis (Duperron et al. 2016). Finally, Bathymodiolus species can be kept in aquaria at atmospheric pressure for extended periods of time, up to several months, facilitating experimental work (Kadar et al. 2005).

Most Bathymodiolus species (e.g. B. thermophilus) host sulfur-oxidizing autotrophic bacteria that use reduced compounds present in environmental fluids as energy sources, and fix carbon through 67 the Calvin-Benson cycle, a process called chemosynthesis. Other Bathymodiolus (e.g. B. platifrons) 
have methane-oxidizing bacteria that use methane as both carbon and energy source. Finally, a few species (e.g. B. azoricus, B. puteoserpentis and B. cf. boomerang) harbor both symbiont types simultaneously inside the same gill epithelial cells (Duperron 2010; Assié et al. 2016; Ponnudurai et al. 2017). Symbionts are acquired from the environment at the post-larval stage, and gill epithelial cells remain competent to acquire bacteria throughout host's life, resulting in coexistence of multiple related symbiont strains (Wentrup et al. 2013; Ansorge et al. 2019). This symbiosis is highly flexible i.e. symbiont's nature and abundances can be modulated by environmental and metabolic host factors. Indeed, symbionts rapidly disappear when their substrates start to run out, and the relative abundances of sulfur- versus methane-oxidizers can vary in response to respective substrate availability (Halary et al. 2008; Szafranski et al. 2015). Moreover, bacterial turn-over inside cells results from bacterial divisions on the one hand, and digestion in phagolysosome-like structures by which hosts get their food, on the other hand (Fiala-Medioni et al. 1994; Dubilier et al. 1998). However, the mechanisms that allow for gill hypertrophy in Bathymodiolus are poorly understood. A recent study investigated the role of apoptosis in the regulation of symbiosis and gill tissue in two Bathymodiolus species, one from the MidAtlantic ridge hydrothermal vents and one from the Regab cold seep site (Piquet et al. 2019). In both Bathymodiolus species, apoptotic levels were highest in the ciliated frontal zone of the gill filaments, (which all together build the side of the gill lamella that is swept by the incurrent seawater flow), and in the circulating hemocytes. It was hypothesized that apoptosis was a consequence of high activity levels of ciliated cells and associated oxidative stress, involving immunity responses from hemocytes of the mussel. The apoptotic rate was comparatively lower in bacteriocytes, in which apoptosis most often occurred in the abfrontal region of the gill filament, opposite to the incurrent seawater flow, where symbionts were least abundant, suggesting ongoing elimination of these bacteriocytes through apoptosis.

To maintain the gills hypertrophy, high apoptotic rates must be compensated by high proliferation rates. In this study, we investigated gill cells proliferation patterns in Bathymodiolus azoricus mussels using microscopic labeling approaches. For this, mussels were incubated experimentally in the presence of a synthetic nucleotide, EdU (5-ethynyl 2'-deoxyuridine), that replaced thymidine in newly synthesized DNA and was revealed by fluorescence microscopy in cell nuclei. As a complementary approach, phosphohistone $\mathrm{H} 3$, a marker of mitosis commonly used in cell proliferation studies, was labeled with a fluorescent antibody. The same experiments were performed in parallel on the non-symbiotic mussel Mytilus edulis for comparison. To our knowledge, this study offers the first attempt to document cell proliferation patterns in deep-sea mussel gills and their relationship with symbiosis.

\section{Materials and methods}

\section{Specimen sampling, EdU incubations and vizualisation}


Bathymodiolus azoricus specimens were collected with the ROV Victor 6000 during the MOMARSAT / BioBaz 2017 cruise (Sarradin and Cannat 2017) on the Lucky Strike site, at the Eiffel Tower edifice $\left(37^{\circ} 17.333 \mathrm{~N} ; 32^{\circ} 16.541 \mathrm{~W}, 1690 \mathrm{~m}\right.$ depth, mean shell length: $\left.71.3 \pm 16.9 \mathrm{~mm}\right)$. Immediately upon recovery, 4 mussels were cut open in the cold room $\left(4^{\circ} \mathrm{C}\right)$ and the gills were dissected without damaging the tissue. Labeling was performed using EdU as an alternative to BrdU (5-bromo2'-deoxyuridine). Attempts with BrdU according to classical protocols (Gratzner 1982; Zaldibar et al. 2004; Gómez-Mendikute et al. 2005; Elisabeth et al. 2012) were also performed on both entire animals and on excised gills, but resulted in low-quality labeling due to tissue damage during the mandatory step of hydrochloric acid denaturation of the tissue (not shown). Moreover, incubations of excised gills of $B$. azoricus on board ensured a direct and time-controlled exposure of the tissues with the marker, whereas incubation of live bivalves with either BrdU or EdU requires greater concentrations and may result in hermetic closure of their shells, which prevents any labeling in the gills.

One gill of each specimen was placed at ambient pressure in a Petri dish containing $0.22 \mu \mathrm{m}$ filtered surface sea water (SFSW) and incubated with Click-it ${ }^{\mathrm{TM}} \mathrm{EdU}$ (5-ethynyl 2'-deoxyuridine, Invitrogen), at $4^{\circ} \mathrm{C}$. Three EdU concentrations were tested : 3, 30 and $100 \mathrm{mg} . \mathrm{L}^{-1}$, during 2 hours incubation experiments (due to onboard constraints), and one gill was incubated for 48 hours (as a very long maximum time) in $3 \mathrm{mg} . \mathrm{L}^{-1}$ EdU. Similar incubations in the presence of EdU, with 5 hours incubation time, were performed on dissected gills of Mytilus edulis collected in Bloscon harbor at Roscoff ( $48^{\circ} 42.975 \mathrm{~N}, 3^{\circ} 57.835 \mathrm{~W}$, mean shell length: $\left.47.3 \pm 2.0 \mathrm{~mm}\right)$, and maintained for one month in Roscoff aquarium service (RAS, $8^{\circ} \mathrm{C}$, filtered natural seawater, fed daily with Isochrysis microalgae). It must be noted that Mytilus mussels remained alive and active throughout this period.

Gills were fixed individually after each experiment using 3.7\% formaldehyde in SFSW, rinsed in SFSW, dehydrated in increasing ethanol series, then embedded in Steedman resin as described in Duperron (2015). Sections ( $8 \mu \mathrm{m}$-thick) were cut on a microtome (Thermo, UK) and placed on SuperFrost Plus slides (VWR, France). Resin was then removed using ethanol. Sections were rehydrated (1X PBS) and permeabilized (0.1\% Triton X-100 and 5\% BSA in $1 \mathrm{X}$ PBS, RT, $30 \mathrm{~min})$. Then, $100 \mu 1$ of the solution included in the "Click it" EdU Kit (Invitrogen, USA) were placed on each slide, for 30 min in a dark room. This solution contains azide coupled to the FITC-fluorochrome, and $\mathrm{CuSO}_{4}$ which catalyzes the reaction. Slides were then rinsed and mounted with Hoechst (Invitrogen, USA) and Vectashield (Clinisciences, Nanterre, France). Slides were observed under a confocal SP5 microscope (Leica, Germany) using filters for DAPI/Hoechst (excitation wavelength: $351 \mathrm{~nm}$; emission at 415$492 \mathrm{~nm}$ ) and EdU (excitation wavelength: $488 \mathrm{~nm}$; emission at 501-602 nm).

\section{Specimen sampling and phosphohistone H3 (PH3) labeling}

PH3 labeling was performed on Bathymodiolus azoricus specimens collected during the BioBaz 
(France 5 marker; $37^{\circ} 17.349 \mathrm{~N} ; 32^{\circ} 16.536 \mathrm{~W}, 2270 \mathrm{~m}$ depth, 4 specimens, mean shell length not recorded). Specimens were sampled using the pressure-maintaining device PERISCOP that retains deep-sea pressure and temperature throughout the recovery process (Shillito et al 2008). Labeling was also performed on 4 specimens of M. edulis from the same sample as above. Gills were fixed, embedded, sectioned and sections were rehydrated as above. Slides were permeabilized in 2\% BSA; $0.3 \%$ Triton X-100 in PBS (2 h, RT). The primary anti-PH3 antibody (polyclonal Ser 10, Merck, Germany) was deposited $\left(5 \mu \mathrm{g} \cdot \mathrm{ml}^{-1} ; 2\right.$ hours RT or overnight at $\left.4{ }^{\circ} \mathrm{C}\right)$. Negative controls were performed by omitting the primary antibody. Slides were then rinsed and incubated with the secondary antibody (goat antirabbit, Invitrogen, USA) coupled to the fluorochrome Alexa Fluor $488\left(5 \mu \mathrm{g} . \mathrm{ml}^{-1}, 1 \mathrm{~h}\right.$, dark humid room). Slides were then rinsed and mounted in DAPI-containing Slow Fade (Life Technologies). They were observed under a confocal SP5 microscope (Leica, Germany) using filters for DAPI/Hoechst (excitation wavelength: $351 \mathrm{~nm}$; emission at 415-492nm) and Alexa 488 (excitation wavelength: $488 \mathrm{~nm}$; emission at 505-655 nm). Images were processed using Image J (Abràmoff et al. 2004).

\section{Results}

EdU labeling reveals differences of proliferation patterns between symbiotic Bathymodiolus and non-symbiotic Mytilus mussels

Non-ambiguous and sharp labeling was found in gills of B. azoricus from Lucky Strike incubated at $3 \mathrm{mg} . \mathrm{L}^{-1} \mathrm{EdU}$ for 48 hours (figure 1), and at the three EdU concentrations for 2 hours (figure 2). As expected for a DNA-based labeling method, the EdU signals were located in cell nuclei, superimposed with Hoechst labeling. The cell proliferation pattern shown in Fig 1 and 2 was observed in all examined filaments. Ciliated cells located at the frontal end of the gill filaments were frequently labeled (figures 1 and 2). The frontal ends together build the side of the gill lamellae swept by the incurrent water flow (figure 1A). In the bacteriocytes zone, dividing cells were more frequent in the bacteriocytes located closest to this frontal zone, (figures 1 and 2). Very few dividing cells were visible in the abfrontal zone (abfrontal ends assembled together build the inner side of each V-shaped gill lamellae, closer to the excurrent flow, see figure 1A). Random and sparse EdU labeling was observed in the lateral zone (figure 1B-E), i.e in the thickness of the gill lamellae, where filaments are aligned side by side, joined by inter-filament ciliary junctions (figure 1A). In the dorsal zone of the gill, where the gill lamellae attach to the visceral mass, cells are not yet fully differentiated. Thus, in the dorsal region ciliated cells and bacteriocytes cannot be identified, however many nuclei were randomly labeled, but not specifically facing the frontal zone (figure $1 \mathrm{~B}$ ).

In Mytilus edulis, few, yet unambiguous labeling was visible at all three EdU concentrations tested. Dividing cells were scattered throughout the gill filaments, mainly in the lateral zones, without any apparent regionalization or clear pattern (figure 3). Interestingly, contrary to B. azoricus, the frontal zones were not labeled in M. edulis. 


\section{Phosphohistone H3 labeling confirms the occurrence of cell divisions}

A few gill cells of B. azoricus from both Menez Gwen site and the deeper Rainbow site were successfully labeled with the PH3-specific antibody. Few labeled nuclei (yet unambiguously labeled) were observed in any given filament section (figure 4A-E). Signals were sharp and consisted of ringlike labels around a nucleus (figure 4B-D), or crescent-like labeling on the distal halves of nuclei of two sister-cells (figure 4E). These were detected in all 7 investigated specimens, from both vent sites. The best staining results were obtained after 2 hours incubation with the primary antibody. In gill filaments, PH3 labeling mostly occurred on nuclei of non-ciliated gill epithelial cells. Qualitatively, dividing cells appeared more abundant on sections from the dorsal region of gills, in the zone of attachment to the visceral mass, where cell types cannot be distinguished, and where DAPI staining reveals a high density of nuclei (figure 4A). No PH3 labeling was present in a total of 10 slides (each comprising several individual filaments) from the four individuals of $M$. edulis (not shown).

\section{Discussion}

\section{Bathymodiolus azoricus gills display regionalized cell proliferation patterns}

Clear evidence of cell division on excised gills of both B. azoricus and M. edulis mussels was observed, even at the lowest tested EdU concentration ( $\left.3 \mathrm{mg} \cdot \mathrm{L}^{-1}\right)$. Because EdU labeling relies on direct fluorescence of the synthetic nucleotide rather than on antibody revelation, the protocol is faster with less permeabilization steps, and thus ensures a better conservation of the tissue structure. To our knowledge, this study is the first application of the EdU protocol on bivalve mollusks and demonstrates its relevance for the study of cell proliferation patterns in this taxon.

Both EdU and PH3 labeling support the evidence of cell proliferation in the dorsal zone of $B$. azoricus gill filaments, where the filaments attach to the mussel's visceral mass. This corroborates previous results by Wentrup et al. (2014) showing abundant proliferating cell nuclear antigen (PCNA) signals in the nuclei of host cells in both juvenile and adult B. puteoserpentis at dorsal ends of gills. This dorsal region initially corresponds to a symbiont-free area (Wentrup et al., 2014). According to our results, a continuous dorsal growth seems to occur in B. azoricus. The ventral zone of the gill filaments is also known to be a growth zone in mussels (Wentrup et al., 2014). However, in the ventral zone our results are not conclusive as the PH3 staining did not exactly co-localize with nuclei. However, towards the ventral part of the gill filaments, we saw EdU labelled cell divisions in the frontal zones (see Fig.1E). The frontal zones are also ciliated cells that are devoid of symbionts. Thus, proliferation of the ciliated cells appears particularly abundant in two symbiont-free zones of the B. azoricus gill, namely the dorsal and the frontal zones. In the bacteriocytes of B. azoricus, which are not ciliated, cell divisions mainly occurred in bacteriocytes close to the frontal ciliated zone. These bacteriocytes are heavily loaded with bacteria (Pernthaler et al. 2008; Wentrup et al. 2014; Piquet et al. 2019). Bacteriocytes located in the 
abfrontal zone, which generally contain fewer symbionts, were almost never undergoing cell division. Despite only qualitative, these observations suggest a regionalized pattern of cell proliferation in $B$. azoricus.

Experiments on excised gills of symbiont-free Mytilus edulis yielded far less abundant EdU labeling with a random distribution in the gill filaments, suggesting that EdU labeling did work, and that proliferation is possibly less regionalized in this species. It must be noted that bacteriocytes found in Bathymodiolus are never ciliated and do not exist in Mytilus, while on the contrary, in Mytilus all gill cells are ciliated throughout the gill lamellae. Interestingly though, frontal ciliated cells exist in both species, and were often labeled in Bathymodiolus, while they were rarely labeled in Mytilus. However, the reasons for this striking difference could also be biological, for example due to the metabolic state of the M. edulis individuals kept in the aquaria. Moreover, experiments with BrdU on M. edulis digestive gland have shown that cell proliferation is far more active in summer than in autumn and winter, and that in intertidal mussels, unlike in subtidal specimens, cell divisions are modulated by a photoperiod with variations following a circa-tidal pattern (Zaldibar et al. 2004, 2008), which might be valid in other tissues as well. Although our coastal mussels were subtidal, an environmentally triggered clock cannot be ruled out, resulting in M. edulis not being in an active phase of cell divisions during our experiment. Thus, the differences in the cell divisions evidenced here between the two mussel-species must be taken with caution.

Positive labeling using the $\mathrm{PH} 3$-specific antibody are in line with previous positive results observed in the symbiotic lucinid clam Codakia orbiculata (Elisabeth et al. 2012) and confirm that the antibody is suitable for the monitoring of bivalve cell mitosis, despite it initially was used in mammalian studies (Hendzel et al. 1997; Hans and Dimitrov 2001; Li et al. 2005). Abundance and patterns of PH3 labeling confirm that cells are undergoing mitosis in B. azoricus gills, possibly more in the dorsal region of the gills. Mytilus edulis gills did not yield labeling, suggesting lower levels of mitosis, but one cannot rule out the alternative hypothesis that the antibody did not work in this species. The existence of physiological differences between mussels from Lucky Strike (used for EdU labeling) and mussels from Menez Gwen and Rainbow (used for PH3 labeling) might explain observed differences in signal abundance between EdU and PH3 in B. azoricus. However, low abundance of PH3 compared to EdU labeling is not surprising. Indeed, EdU is replacing Thymidine in DNA during the S-phase, and remains detectable throughout novel cell divisions (i.e. S-, G2- and M-phases). Thus, EdU is still visible in daughter cells long after they have finished dividing. PH3 on the other hand participates to chromatin condensation, and is only detectable during mitosis (i.e. M-phase), particularly during metaphase (Hendzel et al. 1997). Once mitosis is over, PH3 labeling is not visible anymore, contrary to EdU.

Overall, EdU and PH3 labeling gave qualitatively congruent results. Based on EdU, cell proliferation in B. azoricus seems to be higher in the ciliated cells of the frontal zone and possibly in the bacteriocytes located closest to these ciliated cells. Both EdU and PH3 labeling support that a cell proliferation zone exists in the dorsal region of the gill, supporting that the dorso-ventral growth zone 
of the gill could be due to cell divisions occurring in this region. This dorsal growth zone confirms some of the results obtained by Wentrup et al. (2014) showing abundant proliferating cell nuclear antigen (PCNA) signals in the nuclei of host cells in both juvenile and adult B. puteoserpentis at dorsal ends of gills. The dorsal attachment point is also the ontogenic growth zone in M. edulis (Cannuel et al. 2009). Yet, patterns in M. edulis gills suggest a far less dynamic tissue, with lower abundance and more even distribution of both EdU and PH3 labeling.

\section{A hypothetical model for the overall dynamics of the symbiont-containing gill of B. azoricus}

A recent study has investigated the patterns of apoptosis in the gills of two Bathymodiolus species including B. azoricus from the same sites considered here (Piquet et al. 2019). Apoptosis was regionalized, and levels were higher than in Mytilus edulis. The highest apoptosis rates were measured in the frontal ciliated cells. Higher metabolic activity (and thus oxidative stress of these cells), associated with the larger size of gills, and/or toxic effects associated with the sulfide-enriched fluid from the incurrent seawater flow influenced by hydrothermal fluid, were hypothesized to result in higher apoptotic rates compared to non-symbiotic mytilids. Our study indicates that the frontal ciliated zone is also an area of cell proliferation, suggesting a rapid cell turn-over in this region. Our hypothesis is a necessarily intense and frequent renewal of the frontal ciliated cells that are in the first line, when swept by the incurrent flow containing possible xenobiotics arising from the hydrothermal vents, although the cause for such a phenomenon remains to be determined. By combining the observations on apoptosis and proliferation, we propose a model for the dynamics of the symbiont-containing gill of B. azoricus (figure 5).

In the bacteriocytes zone, apoptosis was more frequent in bacteriocytes located in the abfrontal zone, opposite to the frontal zone, an area where bacterial symbionts are less abundant. Our study shows that proliferation on the other hand occurs in bacteriocytes closest to the frontal zone, where symbionts are the most abundant. We hypothesize that increased cell divisions of these bacteriocytes contribute to increase the total symbiont load. Indeed, upon bacteriocyte division, each daughter cell may inherit host bacterial symbionts, from which its symbiotic population may further grow (by bacterial symbiont division). This could explain some patterns described years ago from cold seep Bathymodiolus heckerae, in which two different sulfur-oxidizing symbionts seemed to colonize distinct patches of bacteriocytes within a given filament (figure 2E-F in Duperron et al. 2007). Under this hypothesis, each individual patch could correspond to daughter cells of distinct initial bacteriocytes that contained one or the other type of symbiont. Alternatively, but not exclusively, daughter cells may be colonized by bacteria released from other bacteriocytes in neighbor gill filaments, as observed in the posterior budding zone of gills from B. azoricus and B. puteoserpentis (Wentrup et al. 2014). The fact that new host cells are produced where symbionts are the most abundant might be an efficient mechanism to maximize the bacterial load in the gill, producing more available space for bacterial growth (figure 5). 
The model (Fig. 5) shows a cross section of a gill filament and highlights the zones where celldivision and apoptosis were observed in our experiments. In summary, the external side of the gill lamellae is constituted by ciliated cells that alternatively undergo apoptosis and cell division, attesting of an intense cellular renewal in this frontal zone, swept by the incurrent water flow. In the thickness of the gill filaments (i.e. the lateral zone), the bacteriocytes closest to the frontal zone were often in cell division, putatively enabling to enhance their load of bacterial symbionts. On the contrary, bacteriocytes close to the abfrontal zone, swept by the excurrent flow, were often in apoptosis. Whether cell divisions and apoptosis are two successively alternating processes within each zone, or whether there is a migration of replicating cells, from the frontal to the abfrontal zone cannot be discriminated from our observations. Indeed, both cell renewal occurring by division of existing cells, and division of undifferentiated putative "stem-cells" migrating afterwards are documented in the symbiotic Codakia lucinid by Elisabeth et al., (2012). Ultrastructural studies in B. azoricus gills are required to further shed light into these putative cellular processes.

To better understand patterns of gill development, future work should focus on the dorsal (for dorso-ventral growth) and posterior budding (for antero-posterior growth) zones of the gill in specimens at various life stages using similar labeling techniques. Finally, the molecular mechanisms that underlie gill tissue dynamics, and the influence of bacterial symbionts on hosts processes, remain to be investigated. Spatial metabolomic at the cellular level seems a promising tool to entangle host-microbe interactions (Geier et al., 2020). These host and symbiont mechanisms may have major roles in the reported adjustments and overall plasticity reported in the association between mussels and chemosynthetic bacteria, which is considered key to their ecological success.

\section{References}

Abràmoff MD, Magalhães PJ, Ram SJ (2004) Image processing with ImageJ. Biophotonics Int 11:3642. https://doi.org/10.1016/j.tcb.2004.03.002

Ansorge R, Romano S, Sayavedra L, et al (2019) Functional diversity enables multiple symbiont strains to coexist in deep-sea mussels. Nat Microbiol 4:2487-2497. https://doi.org/10.1038/s41564019-0572-9

Assié A, Borowski C, van der Heijden K, et al (2016) A specific and widespread association between deep-sea Bathymodiolus mussels and a novel family of Epsilonproteobacteria: Epsilonproteobacterial epibionts of Bathymodiolus. Environ Microbiol Rep 8:805-813. https://doi.org/10.1111/17582229.12442

Cannuel R, Beninger PG, McCombie H, Boudry P (2009) Gill development and its functional and evolutionary implications in the blue mussel Mytilus edulis (Bivalvia: Mytilidae). Biol Bull 217:173188. https://doi.org/10.1086/BBLv217n2p173 
Dubilier N, Windoffer R, Giere O (1998) Ultrastructure and stable carbon isotope composition of the hydrothermal vent mussels Bathymodiolus brevior and $B$. sp. affinis brevior from the North Fiji Basin, western Pacific. Mar Ecol Prog Ser 165:187-193. https://doi.org/10.3354/meps165187 Duperron S (2010) The diversity of deep-sea mussels and their bacterial symbioses. In: Kiel S (ed) The Vent and Seep Biota. Springer Netherlands, Dordrecht, pp 137-167 Duperron S (2015) Characterization of bacterial symbionts in deep-sea fauna: protocols for sample conditioning, fluorescence in situ hybridization, and image analysis. In: McGenity TJ, Timmis KN, Nogales B, editors. Hydrocarbon and Lipid Microbiology Protocols. Berlin, Heidelberg: Springer Berlin Heidelberg. pp. 343-362. https://doi.org/10.1007/8623_2015_73

Duperron S, Quiles A, Szafranski KM, et al (2016) Gill surface areas and symbionts abundances in the hydrothermal vent mussel Bathymodiolus puteoserpentis maintained in pressure vessels. Front. Mar. Sci. 16. https://doi.org/10.3389/fmars.2016.00016 Duperron S, Sibuet M, MacGregor BJ, et al (2007) Diversity, relative abundance and metabolic potential of bacterial endosymbionts in three Bathymodiolus mussel species from cold seeps in the Gulf of Mexico. Environ Microbiol 9:1423-1438. https://doi.org/10.1111/j.1462-2920.2007.01259.x Elisabeth NH, Gustave SDD, Gros O (2012) Cell proliferation and apoptosis in gill filaments of the lucinid Codakia orbiculata (Montagu, 1808) (Mollusca: Bivalvia) during bacterial decolonization and recolonization. Microsc Res Tech 75:1136-1146. https://doi.org/10.1002/jemt.22041 Fiala-Medioni A, Michalski J, Jollès J, et al (1994) Lysosomic and lysozyme activities in the gill of bivalves from deep hydrothermal vents. CR Acad Sci Sci VieLife Sci 317:239-244 Geier B, Sogin EM, Michellod D, Janda M, Kompauer M, Spengler B, Dubilier N \& Liebeke M. (2020). Spatial metabolomics of in situ host-microbe interactions at the micrometre scale. Nature Microbiology 5 (3): 498-510

Gómez-Mendikute A, Elizondo M, Venier P, Cajaraville MP (2005) Characterization of mussel gill cells in vivo and in vitro. Cell Tissue Res 321:131-140. https://doi.org/10.1007/s00441-005-1093-9 Gratzner HG (1982) Monoclonal antibody to 5-Bromo- and 5-Iododeoxyuridine: A new reagent for detection of DNA replication. Science 218:474-475

Halary S, Riou V, Gaill F, et al (2008) 3D FISH for the quantification of methane-and sulphuroxidizing endosymbionts in bacteriocytes of the hydrothermal vent mussel Bathymodiolus azoricus. ISME J 2:284-292

Hans F, Dimitrov S (2001) Histone H3 phosphorylation and cell division. Oncogene 20:3021-3027 Hendzel MJ, Wei Y, Mancini MA, et al (1997) Mitosis-specific phosphorylation of histone H3 initiates primarily within pericentromeric heterochromatin during G2 and spreads in an ordered fashion coincident with mitotic chromosome condensation. Chromosoma 106:348-360 Kadar E, Bettencourt R, Costa V, et al (2005) Experimentally induced endosymbiont loss and reacquirement in the hydrothermal vent bivalve Bathymodiolus azoricus. J Exp Mar Bio Ecol 318:99110 
Lallier F (2013) BIOBAZ 2013 cruise, Pourquoi pas ? R/V. https://doi.org/10.17600/13030030 Li DW, Yang Q, Chen JT, et al (2005) Dynamic distribution of Ser-10 phosphorylated histone H3 in cytoplasm of MCF-7 and CHO cells during mitosis. Cell Res 15:120 Pernthaler A, Dekas AE, Brown CT, et al (2008) Diverse syntrophic partnerships from deep-sea methane vents revealed by direct cell capture and metagenomics. Proc Natl Acad Sci 105:7052-7057 Piquet B, Shillito B, Lallier FH, et al (2019) High rates of apoptosis visualized in the symbiontbearing gills of deep-sea Bathymodiolus mussels. PLOS ONE 14:e0211499. https://doi.org/10.1371/journal.pone.0211499 Ponnudurai R, Kleiner M, Sayavedra L, et al (2017) Metabolic and physiological interdependencies in the Bathymodiolus azoricus symbiosis. ISME J. 11:463-477 https://doi.org/10.1038/ismej.2016.124 Russell S, Ruelas Castillo J (2020) Trends in Symbiont-Induced Host Cellular Differentiation. Available at preprints.org. https://doi.org/10.20944/preprints202004.0172.v2 Sarradin P-M, Cannat M (2017) MOMARSAT2017 cruise, Pourquoi pas ? R/V Szafranski KM, Piquet B, Shillito B, et al (2015) Relative abundances of methane- and sulfuroxidizing symbionts in gills of the deep-sea hydrothermal vent mussel Bathymodiolus azoricus under pressure. Deep Sea Res Part Oceanogr Res Pap 101:7-13. https://doi.org/10.1016/j.dsr.2015.03.003 Shillito B, Hamel G, Duchi C, Cottin D, Sarrazin J, Sarradin P-M, et al. Live capture of megafauna from 2300m depth, using a newly designed Pressurized Recovery Device. Deep Sea Res Part Oceanogr Res Pap 2008; 55:881-9. https://doi.org/10.1016/j.dsr.2008.03.010 Wentrup C, Wendeberg A, Huang JY, et al (2013) Shift from widespread symbiont infection of host tissues to specific colonization of gills in juvenile deep-sea mussels. ISME J 7:1244-1247. https://doi.org/10.1038/ismej.2013.5 Wentrup C, Wendeberg A, Schimak M, et al (2014) Forever competent: deep-sea bivalves are colonized by their chemosynthetic symbionts throughout their lifetime: Symbiont colonization in gills of deep-sea bivalves. Environ Microbiol 16:3699-3713. https://doi.org/10.1111/1462-2920.12597 Zaldibar B, Cancio I, Marigomez I (2004) Circatidal variation in epithelial cell proliferation in the mussel digestive gland and stomach. Cell Tissue Res 318:395-402. https://doi.org/10.1007/s00441004-0960-0

Zaldibar B, Cancio I, Marigómez I (2008) Epithelial cell renewal in the digestive gland and stomach of mussels: season, age and tidal regime related variations. Histol Histopathol 23:281-290. https://doi.org/10.14670/HH-23.281 
396 BP was funded through a joint grant from Région Bretagne and Sorbonne University (project 397 FlexSyBi) and labwork was funded by Institut Universitaire de France project ACSYMB. The 398 pressure-maintaining device PERISCOP was funded by the EC project EXOCET/D (FP6-GOCE-CT399 2003-505342). The funders had no role in study design, data collection and analysis, decision to 400 publish, or preparation of the manuscript.

401 Conflicts of interest/Competing interests (include appropriate disclosures)

402 The authors have declared that no competing interests exist.

403

404 Ethics approval

405 No specific permissions were required for the sampled locations, and the study did not involve 406 endangered or protected species.

407

408 Consent to participate: not applicable

409 Availability of data and material

410 All relevant data are within the manuscript.

411 Authors' contributions

$412 \mathrm{SD}, \mathrm{ACA}$ and BP designed the study, analyzed the data and wrote the original draft of the manuscript.

413 SD, ACA, BS and FHL obtained the funding

$414 \quad$ BP and CA conducted the labwork

415 FHL and BS were involved in study design, field work during cruises.

416 All authors have read, reviewed, and agreed on the manuscript. 

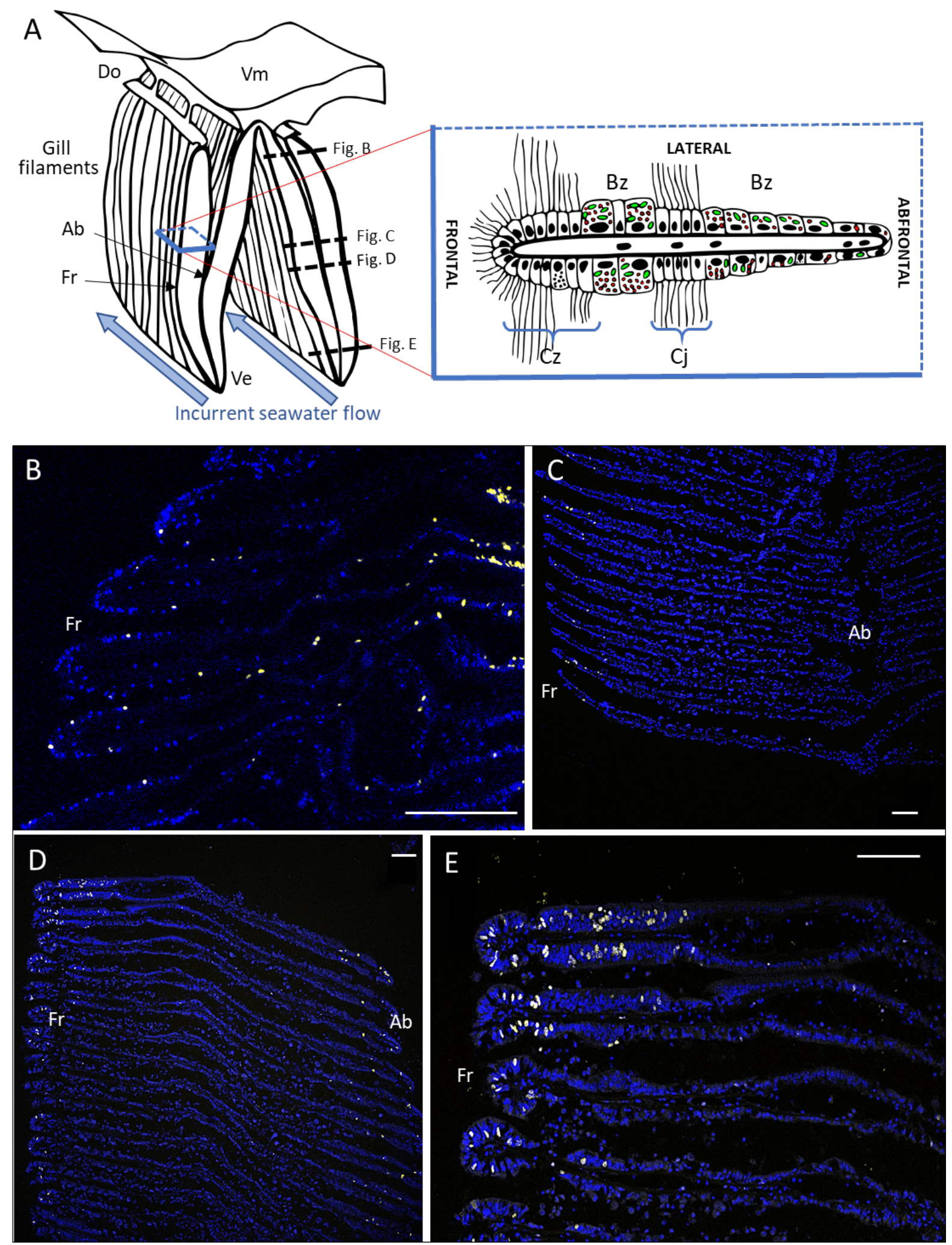

Figure 1: Serial gill cross sections of Bathymodiolus and associated EdU and Hoechst labeling. A: localization of sections in the dorso-ventrally oriented (Do; Ve) W-shaped gill, attached in its dorsal part to the visceral mass $(\mathrm{Vm})$, displaying the orientation of individual gill filaments (frontal; Fr and abfrontal Ab; modified from Le Pennec and Hily, 1984); and (right) detail of a gill filament section composed of frontal, lateral and abfrontal zones. Frontal sides refer to the external sides of the gill lamellae directly facing the seawater current within the mantle cavity, while the abfrontal sides refer to their inner sides, facing either V-shaped cavity of the gills. Host nuclei 
426 are in black, while sulfur- and methane-oxidizing symbionts are in red and green, respectively. The frontal zone

427 consists of ciliated cells $(\mathrm{Cz})$, the lateral includes bacteriocytes zones $(\mathrm{Bz})$ as well as ciliated junctions $(\mathrm{Cj})$, while

428 the abfrontal zone consists of thinner bacteriocytes with very few symbionts. B-E: EdU labeling (3mg. $\mathrm{L}^{-1}$ EdU,

42948 hours) on some of the 14 obtained serial sections, cut from the dorsal (B) to the more ventral region of the gill

430 (E). Hoechst (blue) labels the nuclei and symbiotic bacteria, and EdU (yellow) labels the nuclei of the cells which

431 have undergone cell division during EdU incubation. Note the comparative abundance of labeled cells and their

432 distribution in the dorsal region (B), compared to the more ventral region (C-E) where most of the EdU-labeled

433 cells are located in the frontal zone of the filaments, while abfrontal zones are mostly devoid of labeling. Very few

434 cells appear labeled in the bacteriocyte zone where bacteriocytes and ciliated junctions also are present. Scale

435 bars: $100 \mu \mathrm{m}$.

436 


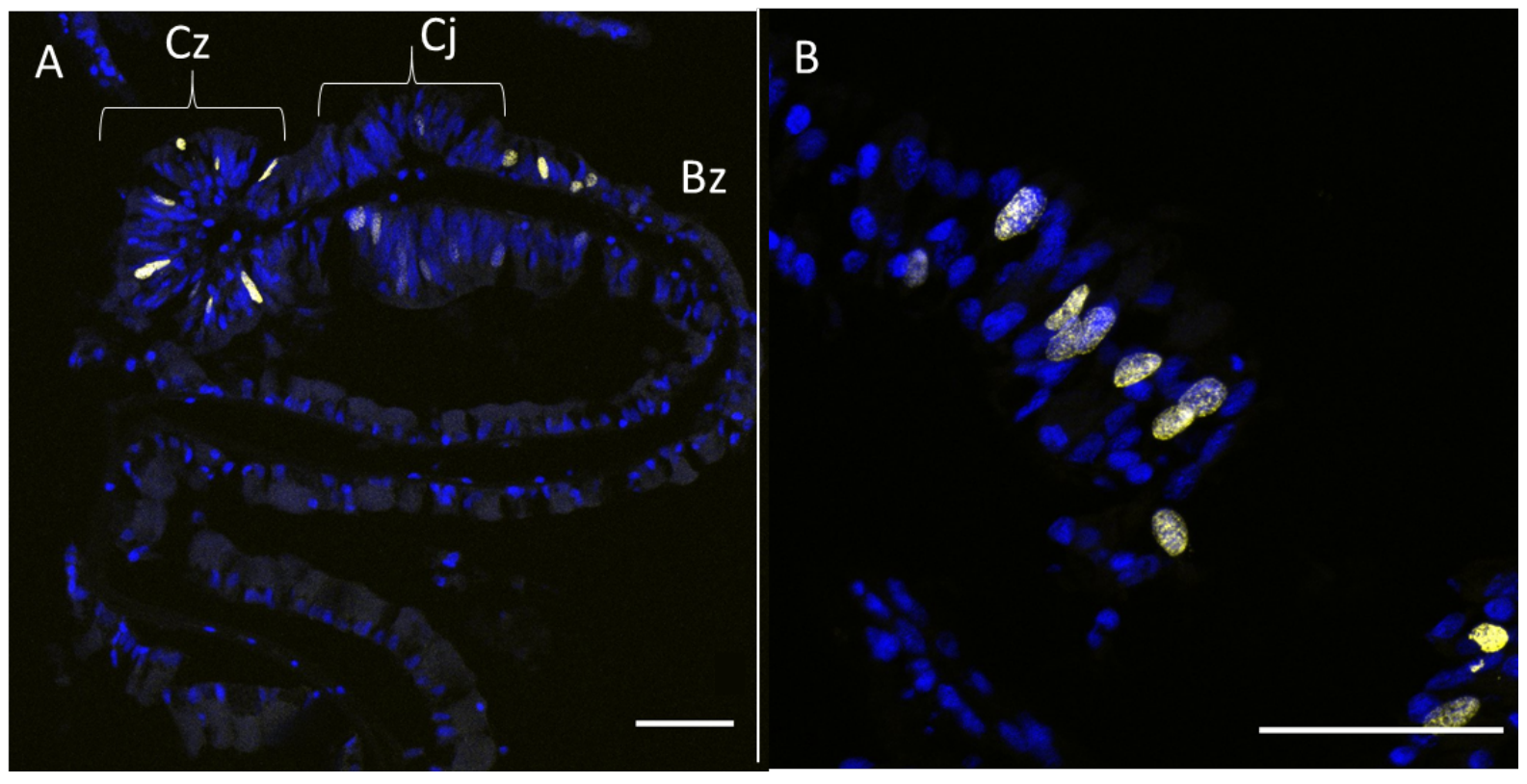

441 Figure 2: Gill filaments of Bathymodiolus azoricus labeled with EdU (3mg.L-1 EdU, 2 hours). Hoechst (blue) labels the nuclei and symbiotic bacteria, and EdU (yellow) labels the nuclei of the cells which have undergone cell division during EdU incubation. A: Frontal zone of the filament with the frontal ciliated zone $(\mathrm{Cz})$, the ciliated inter-filament junction $(\mathrm{Cj})$ and the bacteriocytes zone $(\mathrm{Bz})$. Note that most EdU labeled cells are located in the $\mathrm{Cz}$ and $\mathrm{Cj}$, and in the most frontal zone of bacteriocytes, close to $\mathrm{Cj}$, while the more distant area of Bz is devoid of labeling. B: Detail of a ciliated zone, showing nuclei at various stages of cell division. Scale bars: $50 \mu \mathrm{m}$. 

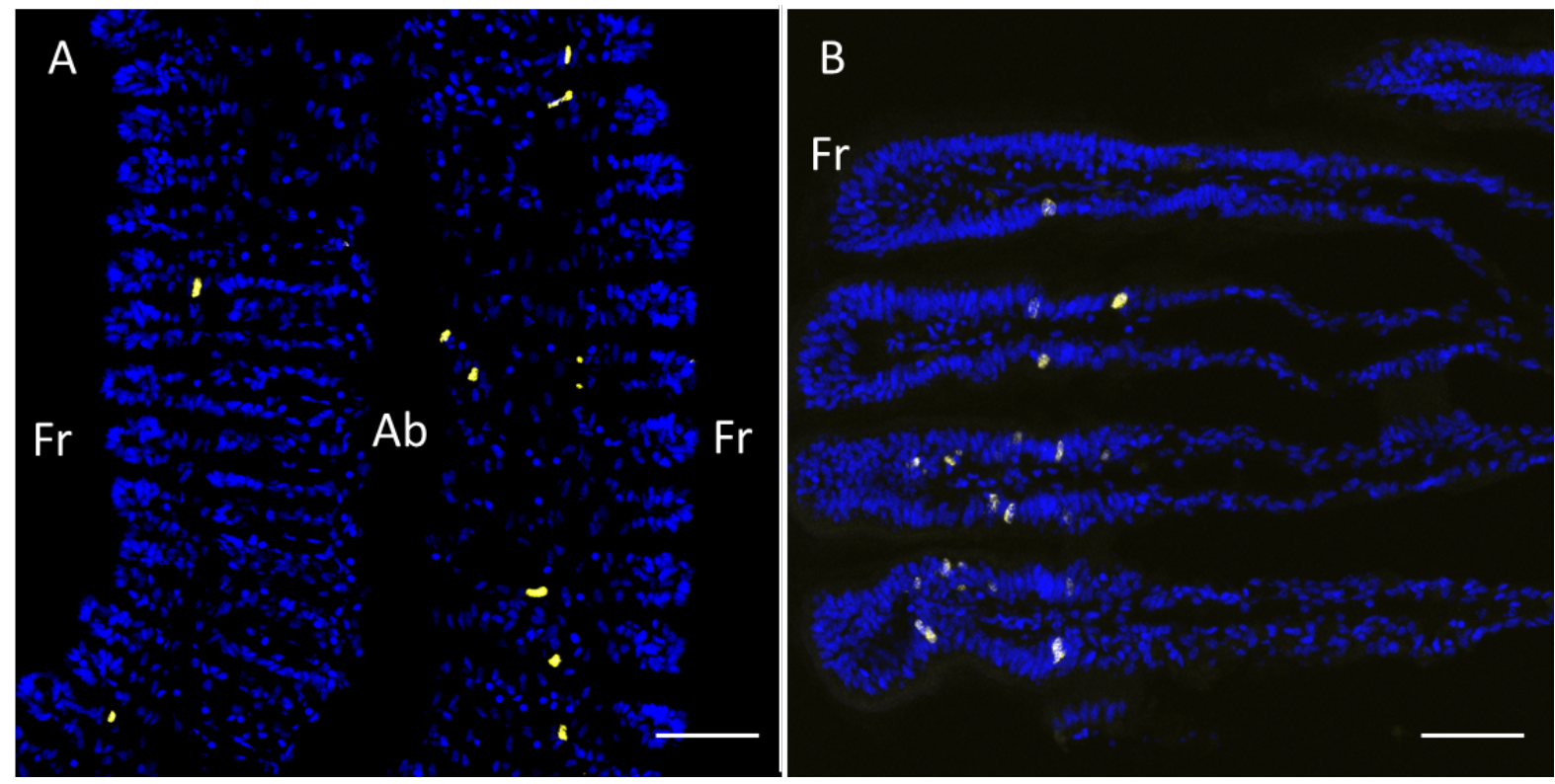

451

452 Figure 3: Cell proliferation patterns in isolated gills of Mytilus edulis. Hoechst (blue) labels nuclei, and EdU 453 (yellow) labels nuclei of cells undergoing division; frontal (Fr) and abfrontal ( $\mathrm{Ab}$ ) zones are indicated. A: 3 mg.L$454{ }^{1}$ EdU for 5 hours incubation. B: $100 \mathrm{mg} . \mathrm{L}^{-1}$ EdU for 5 hours incubation. Scale bars:50 $\mu \mathrm{m}$. 


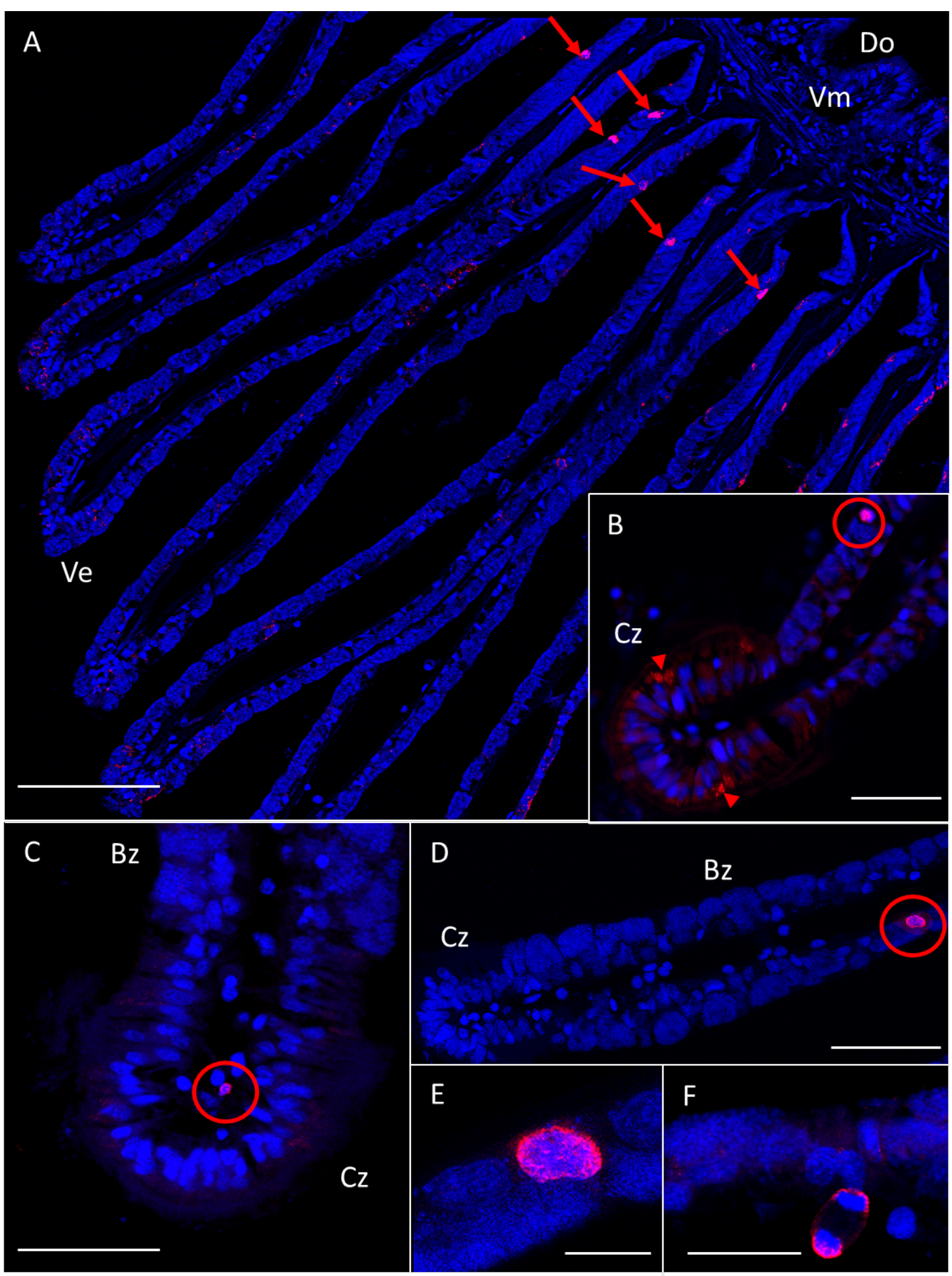

Figure 4: Gill filaments of Bathymodiolus azoricus labeled with DAPI (blue) and anti-PH3 antibody (pink). A:

459 Ventral (Ve) to dorsal (Do) parasagittal section of the gill showing several PH3-labeled cells (red arrows) on the dorsal side near the visceral mass $(\mathrm{Vm})$. Scale bar : $100 \mu \mathrm{m}$. B: Detail displaying an unambiguous label overlapping with DAPI-labeled nuclei (circled), versus labels that do not overlap with nuclei in the ciliated zone 
462 (Cz; arrowheads), likely representing non-specific labeling. Scale bar : 50 $\mu \mathrm{m}$. C: The red circle marks a hemocyte

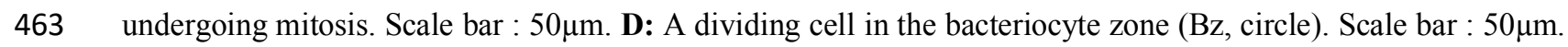

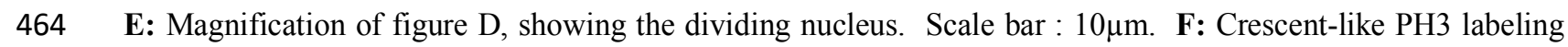

465 located around the nuclei of two daughter cells shortly after anaphase. Scale bar : $20 \mu \mathrm{m}$.

466 


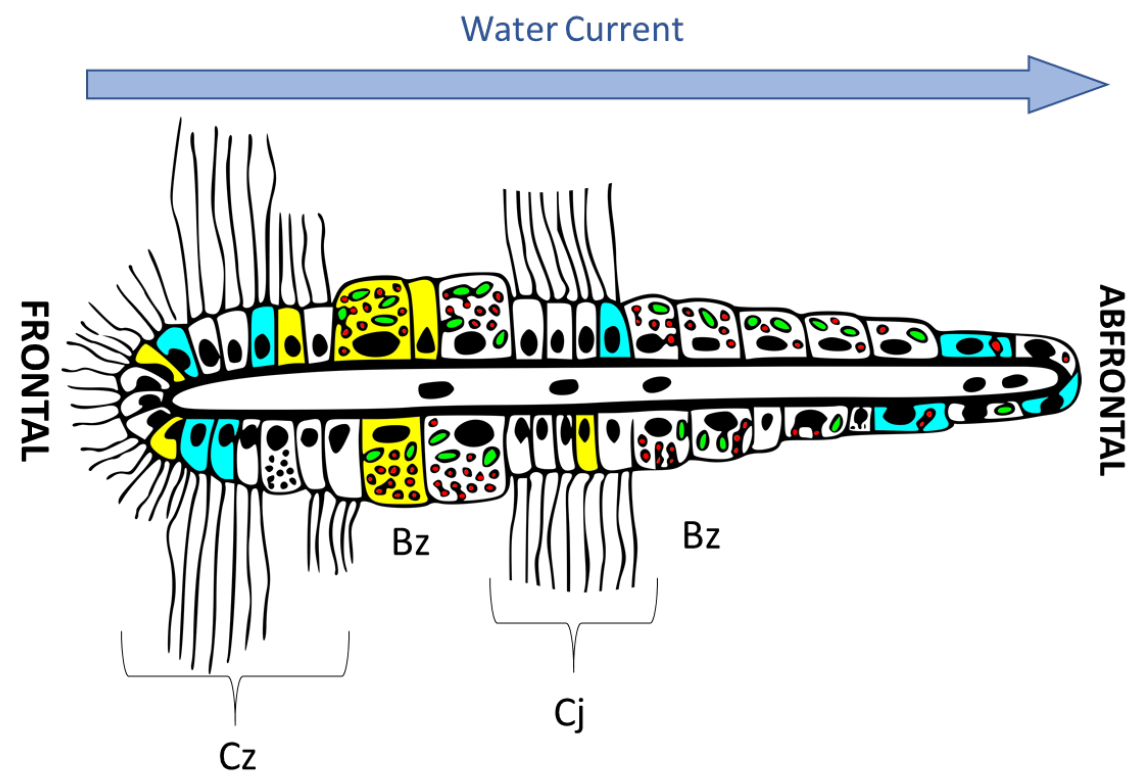

469 Figure 5: Schematic cross section of a gill filament of Bathymodiolus azoricus summarizing observations from 470 this study. Areas of cell multiplication are in yellow, mostly located in the frontal ciliated zone $(\mathrm{Cz})$ and in the 471 bacteriocytes zone $(\mathrm{Bz})$ located near the frontal zone. Areas of cell apoptosis are in cyan, also abundant in the 472 frontal ciliated zone, but also in the abfrontal zone $(\mathrm{Ab})$ where bacteriocytes tend to be thinner and almost devoid 473 of bacterial symbionts (after Piquet et al. 2019). Other abbreviations; ciliated junction (Cj). 